\title{
Profitability Paradox: Evidence from Commercial Banks in Pakistan
}

\author{
Aatir Hamid $^{1 *}$, Bilal Mehmood ${ }^{1}$, Nisar Ahmad ${ }^{2}$
}

\begin{abstract}
It is generally believed that information technology (IT) impacts the organizational profitability positively, however, empirical evidence has remained inconclusive. This was first highlighted by Solow (1987), labelled as Solow's paradox, and later labelled as profitability paradox by Beccalli (2007). The persistence of inconclusive empirical literature provides the impetus of this research to investigate the impact of different components of IT on banks profitability in Pakistan from 2009-2016 for a sample of 25 Pakistani commercial banks. Return on assets (ROA) and return on equity (ROE) have been used as indicators of bank profitability, whereas two different components of IT, number of ATMs and investment in banks software have been employed as proxies of IT. Empirical results reveal that investment in bank software appears to have a positive influence on bank profitability, while the acquisition of ATMs seems to reduce the profitability of banks. It can be concluded that IT paradox is not necessarily a paradox of IT in totality and may be termed as IT component paradox.
\end{abstract}

Keywords: Information technology (IT), Return on assets (ROA), Return on equity (ROE), Bank Software, and Difference generalized method of moments.

\section{Introduction}

Over the last five decades, economies world over witnessed revolutionary development that could be credited to various macro determinants such as innovation, globalization, competition and deregulation, and possibly the most distinct force catalyzing these development is the Information Technology (Dos Santos \& Sussman, 2000). In today's dynamic business environment, the role of IT in strengthening firm's competitiveness has increased manifold (Lee, Choi, Lee, Min \& Lee 2016). Today, organizations have widely engaged IT in a number of ways according to their business requirements. For instance, enterprise resource planning systems, are being purchased and implemented by manufacturing and banking firms to streamline business transactions, operations and resource management (Shaoa \& Lin, 2002).

${ }^{1}$ Government College University, Lahore

${ }^{2}$ Hailey College of Commerce. University of the Punjab, Lahore.

*Corresponding Author: aatirpk@hotmail.com

This work is Licensed under a Creative Commons Attribution-Noncommercial 4.0 International License 
In the modern era, IT is at the core of banking industry operations and product development, whereas banking industry itself is the backbone of every economy (Abubakar \& Tasmin, 2012). Commercial banks, by the very nature of their business, are highly information intensive businesses. The business carried out by them is greatly dependent on information pertaining to the management of banks financial resources, deposits, advances, customer databases as well as regulatory directives from the central bank and other regulatory and legal authorities that define the rules and operations of the banking business. Use of IT has been considered as one of main contributions towards productivity of banks (Swierczek \& Shrestha, 2003). Both the rising costs of IT and the importance of benefits offered by it are two differing aspects of IT and have over the time given rise to an interesting and intriguing paradox. Organizations often do not succeed in taking benefit from opportunities that these investments could potentially engender. Banks essentially passed forward the benefits, to customers, from the revolutionary technological advance of automated teller machine in the decade of eighties mainly due to increasingly competitive environment existing in the industry (Berger, 2003).

Interestingly, the phenomena of "IT paradox" was first underscored by a Nobel Laureate Robert Solow in 1987, who in a famous quip laconically portrayed the IT paradox: "you can see the computer age everywhere, but not in the productivity statistics" and since then it has remained the center of research work carried out on the subject. Later, Beccalli (2007) examined the link of IT to profitability. His empirical estimation revealed that investment in IT enhanced the bank profitability. He indicated the existence of a paradoxical situation and coined the term of "profitability paradox". There is much doubt and opacity that exists about the effects of IT on organizational financials (Brynjolfsson, 1993). This paradox phenomenon has been claimed, unclaimed and reclaimed in literature over time. Dos Santos and Sussman (2000) further state that this paradoxical situation has existed for all main IT innovations ever since the introduction of computers: from database management systems, simple transaction processing systems and once systems, and the present wave of applications triggered and generated by the speedy developments of world wide web i.e. Internets. Normally, it is believed that firms making substantial IT related investments should be remunerated with greater financial returns (Stratopoulos and Dehning, 2000), but it must be startling to observe that the available evidence related to subject matter, conversely, reveals some differences in concluding the influence of IT towards profitability of banks (Ho and Mallick, 2006). The persistence of inconclusive empirical literature about impact of IT on banking sector's profitability and the surprising presence of profitability paradox indicate existence of an unsolved phenomena. Therefore, this research attempts to address this shortfall and investigates the impact of different components of IT on banks profitability in Pakistan.

The remaining of the paper is designed as follows. Section 2 outlines the problem statement and objectives. Section 3 highlights the overview of Pakistan's Banking Sector from IT Perspective. Section 4 offers literature review. Section 5 describes the

Sukkur IBA Journal of Management and Business - SIJMB | Volume 5 No. 2 July - December 2018 @) Sukkur IBA University 
hypothesis of the study and sample selection. Section 6 deals with Empirical Strategy, Results and Discussion. The final section offers conclusion and future research.

\section{Literature Review and Hypothesis}

The business value of IT has been debated for a number of years and has been the focal point of numerous editorials, news articles, research projects and books. Most of the research work studying impact of IT on business performance since 1980's hops around the Solow's Paradox that raised suspicions about the impact of IT on productivity in US economy (Solow, 1987).

Kauffman and Banker (1991) found that teller labor reduced due to presence of ATMs and the bank's ATM network was found to be a vital determinant of the relative share of the retail deposit market a bank may capture. Hitt and Brynjolfsson (1996) studied business value of IT from three different perspectives productivity, profitability and consumer surplus. Their findings, indicate that IT has increased productivity and has created considerable value for consumers. Similarly, Parsad and Harker (1997) reported that IT investment has zero or insignificant effect on bank profitability. They further argue that additional investment of capital in IT may have no actual paybacks and, profits and may be more of a strategic necessity to stay competitive along with other banks in the industry. Thus, according to them in the competitive environment of US retail banking industry, IT is not expected to make significant impacts on the firm's profitability.

Berger (2003) stated that the effect of internet banking is not much clear because of limited experience with the technology. Swierczek and Shrestha (2003) reveal that Asia-Pacific banks have employed IT in a more productive manner than Japanese banks. They further state that IT products impacts productivity in a positive manner and use of IT rises outputs and reduces costs. Shu and Strassmann (2005) examined the role of IT in providing banks with profit. Their dataset comprises a panel of 12 US banks from 1989-1997. They used IT budget and revenue as proxies for IT and bank profitability respectively. Upon applying panel data random effect model results show that there is positive relation between investment in IT and bank profitability. They opine that due information intensive nature of banking industry benefits of substituting labor with IT are not surprising.

As much of the work on the subject has been focused on US banking sector, Beccalli (2007) investigated whether or not investment in IT impacted bank performance in five EU countries France, Germany, Italy, Spain and UK. The findings revealed weak relationship between investments in IT and bank profitability. Hence, indicating the existence of a profitability paradox in European banking industry. Beccalli argues that role of IT for banks may not be profit oriented and rather a strategic necessity. However, he points out that impact of different forms of IT on bank profitability is heterogeneous. Ho and Mallick (2010) examined the effects of IT in the US banking industry. The evidence confirms the presence of IT profitability paradox in the US banking industry and suggests that IT may help banks in cost savings, but these cost savings are not

Sukkur IBA Journal of Management and Business - SIJMB | Volume 5 No. 2 July - December 2018 @ Sukkur IBA University 
sufficient to offset the loss due to competition, resulting in an overall negative effect of IT on industry's revenues. Mehmood et al. (2014) established the absence of Solow's paradox in 47 of the world's leading capital markets. They reported that Stock markets are positively affected by the use of advanced technology and communication means. However, sometimes they can be negatively affected due to high operating and infrastructure costs, lack of skilled staff to handle the latest technology, operating failures and defected IT products containing computer viruses.

Though there have been studies that reported a positive relationship between IT and business performance, which is contrary to Solow's paradox, Acemoglu, Autor, Dorn, Hanson, and Price (2014) claim the return of Solow's paradox, they have documented growth pattern of different manufacturing industries and have challenged the technological-discontinuity view, which says that sophisticated technological transformations due to IT have positively impacted the businesses. They argue that ITintensive industries in USA have not even registered a fast growth as compared to nonIT-intensive industries and there is a very minute productivity growth in such industries. Mustafa and Mehmood (2015) reported that technical efficiency and total factor productivity of banks in Pakistan have been significantly increased in post-digital reform era. Lee, et al. (2016) suggested that seeing constant upsurges in IT investment, the IT itself cannot create value rather what matters is the way IT is employed to generate business outcomes. Campanella, Della Peruta, and Del Giudice (2017) in a study of 3190 banks located in 17 countries report that the innovations relating to enterprise resource planning software systems increase the earning margin of banks. Vekya (2017) in a study of 43 Kenyan banks found out that there is a positive significant association between ATM transactions and bank profitability whereas mobile transactions do not influence performance of commercial banks. Tahir, et al. (2018) recommends that banks in Pakistan must make more investments in ATMs and POS channels as they result in reduction of operating expenses for the banks. Thakur (2018) concludes that Indian banking industry has highly benefited from IT implementation. IT has provided Indian banks with advanced product development, better market infrastructure, execution of reliable techniques for risk control and has helped the financial intermediaries to tap new markets. Mahboub (2018) reported that the implementation banking technologies such as ATM, internet banking does not significantly affect the performance of the banks in Lebanon. The study argues that the costs of implementing these technologies by Lebanese banks exceed their benefits. Gupta, et al. (2018) examined the existence of profitability paradox in Indian Banking Sector using Stochastic Frontier Analysis. Empirical findings confirmed the presence of profitability paradox.

It has been much pondered over whether or not IT can provide improvements in profitability or business efficiency. This review shows that in spite of theoretical arguments and professional belief in favor of a positive relation between IT and superior financial performance there is no agreement on impact of IT on bottom line business profitability in empirical literature. Businesses continue to spend on IT, yet the evidence

Sukkur IBA Journal of Management and Business - SIJMB | Volume 5 No. 2 July - December 2018 @ Sukkur IBA University 
has shown no conclusive answer to whether or not their profitability has gone up, therefore, more research is necessary to clarify the relationship between IT and profitability.

The study intends to test the following hypothesis:

$\mathbf{H}_{0}$ : Different components of IT do not significantly impact commercial banks, profitability in Pakistan.

$\mathbf{H}_{\mathrm{A}}$ : Different components of IT significantly impact commercial banks, profitability in Pakistan.

\section{Data and Estimation Methodology}

We used the secondary data pertaining to variables employed in the study from annual reports of commercial banks. Dependent variable, profitability is measured by using return on assets (ROA) and return on equity (ROE). Independent variables include investment in bank software number of ATMs and size of banks. The sample of this study comprises 25 Pakistan based commercial banks ${ }^{3}$ of which there are 3 public sector banks, 21 domestic private sector banks and 01 foreign bank. All commercial banks have been included in the sample pertaining to which annual data was available over the time span of 2009-2016, making a pooled total of 990 observations.

As in the panel of this research, there are 25 banks $(\mathrm{N})$ and a time dimension of 08 years $(\mathrm{T})$. Therefore, the number of banks $(\mathrm{N})$ is greater than number of time periods $(\mathrm{T})$. In such a case Pooled OLS, IV regression are widely believed to be inconsistent ${ }^{4}$ (Roodman, 2009) therefore, Generalized method of moments becomes a preferred choice as this technique is specially developed for situations wherein " $T$ " is lesser as compared to "N" to address for dynamic panel bias (e.g. Bond, 2002; Roodman, 2006; Roodman, 2007 and Sarafidis et al., 2009). GMM estimators are extended forms of a lot of usual estimation techniques such as instrumental variable regression and ordinary least square, there are clear benefits of preferring GMM over IV; in case there is heteroskedasticity in data, the GMM is a better and more efficient option than a usual IV estimator. Also, in case of absence of heteroskedasticity, the GMM estimation

${ }^{3}$ Following banks constitute the panel for this study; First Women Bank Limited, National Bank of Pakistan, Bank of Khyber, Al-Baraka Bank Limited, Allied Bank Limited, Askari Bank Limited, Bank Al Habib Limited, Bank Alfalah Limited, Bank Islami Pakistan Limited, Dubai Islamic Bank Pakistan Limited, Faysal Bank Limited, Habib Bank Limited, Habib Metropolitan Bank Limited, JS Bank Limited, MCB Bank Limited, Meezan Bank Limited, NIB Bank Limited, Samba Bank Limited, Silk Bank Limited, Soneri Bank Limited, Standard Chartered Bank Limited, Summit Bank Limited, United Bank Limited, Citi Bank and Burj Bank Limited.

${ }^{4}$ Due to the problems of endogeneity, autocorrelation unobserved heterogeneity and heteroscedasticity.

Sukkur IBA Journal of Management and Business - SIJMB | Volume 5 No. 2 July - December 2018 @ Sukkur IBA University 
technique is no worse asymptotically as compared to the IV estimator (Baum, Schaffer \& Stillman, 2003).

Several authors (Bond, 2002; Roodman 2006; Roodman, 2007) state that SGMM could be a preferred option over DGMM if variables are "random walk" or close to be random-walk variables. Usually microeconomic or firm specific variables are usually close to stationary. Therefore, DGMM will be a preferred choice for the purpose of this research over SGMM which is more suitable for random walk variables (Efendic, Pugh \& Adnett, 2009).

\section{Empirical Models}

Investigation of different empirical specifications in existing literature reveal that ROA and ROE have been widely employed as a measure of bank profitability (Rauf, Qiang \& Sajid, 2014; Karimzadeh, Emadzadeh \& Javad Shateri, 2014; Jesudasan, Pinto \& Prabhu, 2013; Onay, Ozsoz \& Helvacıŏlu, 2008; Hernando \& Nieto; 2007; Beccalli, 2007; Mittal \& Dhingra, 2007; Eyadat \& Kozak, 2005; Stratopoulos \& Dehning, 2000). Different proxies of IT have been used in literature to examine the impact of IT on profitability of banks in the form of index and in components, as in this research the impact is to be measured in components, Therefore, number of ATMs and investment in bank software have been employed as proxies of IT. Number of ATMs as a proxy of IT has been used in various studies (Karimzadeh et al., 2014; Jesudasan et al., 2013; Ou, Yen \& Hung, 2009; Holden \& El-Bannany, 2004; Alpar \& Kim, 1990), investment in bank software has also been employed as a proxy of IT in literature by different researchers (Safari \& Yu, 2014; Jesudasan et al., 2013; Jalal-Karim \& Hamdan, 2010; Beccalli 2007). IT components are part of a multitude of factors that affect banks returns to control for other factors and for a more comprehensive and theoretically robust model to examine the relationship amongst IT and bank profitability bank size represented by total assets has been added as a control variable. Bank size has been used as a control variable in existing literature by several authors (Karimzadeh et al., 2014; Safari \& Yu, 2014; Ou, Yen \& Hung, 2009). Therefore, the following two models are estimated empirically to measure the impact of IT on commercial banks profitability;

$$
\begin{aligned}
& \operatorname{ROA}_{\mathrm{i}, \mathrm{t}}=\beta_{0}+\beta_{1} \mathrm{ROA}_{\mathrm{i}, \mathrm{t}-1}+\beta_{2} \mathrm{LNBS}_{\mathrm{i}, \mathrm{t}}+\beta_{3} \mathrm{LATM}_{\mathrm{i}, \mathrm{t}}+\beta_{4} \mathrm{LNTA}_{\mathrm{i}, \mathrm{t}}+\mu_{\mathrm{i}, \mathrm{t}} \ldots \ldots \ldots \ldots \text { model } 1 \\
& \mathrm{ROE}_{\mathrm{i}, \mathrm{t}}=\beta_{0}+\beta_{1} \mathrm{ROE}_{\mathrm{i}, \mathrm{t}-1}+\beta_{2} \mathrm{LNBS}_{\mathrm{i}, \mathrm{t}}+\beta_{3} \mathrm{LATM}_{\mathrm{i}, \mathrm{t}}+\beta_{4} \mathrm{LNTA}_{\mathrm{i}, \mathrm{t}}+\mu_{\mathrm{i}, \mathrm{t}} \ldots \ldots \ldots \ldots \ldots \text { model } 2
\end{aligned}
$$

Where,

ROA $_{i, t}:$ Return on Asset

$\mathbf{R O E}_{i, t}$ : Return on Equity

$\mathbf{R O A}_{\mathrm{i}, \mathrm{t}-1}$ : lagged value of Return on Assets

$\mathbf{R O E}_{\mathrm{i}, \mathrm{t}-1}$ : lagged value of Return on Equity

LNBS $_{\mathrm{i}, \mathrm{t}}$ : logged value of Bank Software investments

LATM $_{i, t}:$ logged value of number of ATMs

LNTA $_{i, t}:$ logged value of total assets

Sukkur IBA Journal of Management and Business - SIJMB | Volume 5 No. 2 July - December 2018 @ Sukkur IBA University 
$\boldsymbol{\mu}_{\mathrm{i}, \mathrm{t}}:$ error term

$\boldsymbol{\beta}:$ intercept

Subscript i: bank i and

Subscript t: time $\mathrm{t}$

To correct for potential endogeneity bias, relevant lagged dependent variables have been added in both the models, whereas independent variables natural logarithm has been taken to correct for heteroscedasticity.

\section{Results and Discussion}

Table 1: Descriptive Statistics

\begin{tabular}{lcccc} 
& Mean & Minimum & Maximum & Standard Deviation \\
\hline ROA & 0.4489 & -7.5127 & 5.6669 & 2.0097 \\
ROE & 1.4076 & -268.7462 & 139.4631 & 36.7332 \\
$\begin{array}{l}\text { Investment in } \\
\text { Bank Software }\end{array}$ & 190708725 & 00 & 1496040000 & 292436848.4280 \\
$\begin{array}{l}\text { Number of } \\
\text { ATMs }\end{array}$ & 176.0051 & 03 & 1303 & 191.3090 \\
Bank size & 265338975885 & 2695837000 & 1612657805000 & 301676854242.5680
\end{tabular}

Source: Author's computation using Stata version 12.0

Table 1 indicates that averagely banks in our sample are getting 44 rupees on utilizing the assets of 100 rupees and 140 on equity which displays that banks are utilizing the funds of equity in a better way. Standard deviations of both variables show that ROE has more fluctuations as compared to ROA. Bank software is an intangible asset of the bank and is charged with amortization, additions and deletions every year and reported in financial statements. The Minimum value of bank software can be seen as zero which indicates a fully amortized net zero value of the asset and such observations are very few in whole range of values of this variable in the sample of this research. The maximum value for bank software goes to more than a billion and indicates its importance as one of the major capital expenses of the bank. Such range of minimum and maximum values of the bank software for the so mentioned reasons tantamount to a high mean and standard deviation of this variable. Variation in Number of ATMs and bank size is due to fact that the sample includes both large and small banks, large banks have large total assets and small banks report a smaller figure of total assets, Similarly, large banks have a greater geographical reach and thus have a large number of ATM's in order to serve their customers, whereas small banks due to their small geographical presence have a low number of ATMs in place.

Sukkur IBA Journal of Management and Business - SIJMB | Volume 5 No. 2 July - December 2018 @ Sukkur IBA University 
Table 2: Correlation Analysis

\begin{tabular}{|c|c|c|c|c|}
\hline ROA & $\begin{array}{l}\text { Investment in } \\
\text { Bank Software }\end{array}$ & No. of ATM & Total Assets & \\
\hline ROA & 1.0000 & & & \\
\hline $\begin{array}{l}\text { Investment in } \\
\text { Bank Software }\end{array}$ & $0.1175^{*}$ & 1.0000 & & \\
\hline No. of ATM & $0.3433 *$ & $0.5268 *$ & 1.0000 & \\
\hline Total Assets & $0.3594 *$ & $0.3859 *$ & $0.7942 *$ & 1.0000 \\
\hline Vif & 1.39 & 3.20 & 2.72 & \\
\hline $1 /$ vif & 0.71 & 0.31 & 0.36 & \\
\hline
\end{tabular}

Source: Author's computation using Stata version 12.0

\begin{tabular}{|c|c|c|c|c|}
\hline ROE & $\begin{array}{c}\text { Investment in } \\
\text { Bank Software }\end{array}$ & No. of ATM & Total Assets & \\
\hline ROE & 1.0000 & & & \multirow{7}{*}{1.0000} \\
\hline Investment in & 0.1072 & 1.0000 & & \\
\hline \multicolumn{5}{|l|}{ Bank Software } \\
\hline No. of ATM & $0.2397 *$ & $0.5268 *$ & 1.0000 & \\
\hline Total Assets & $0.2250 *$ & $0.3859 *$ & $0.7942 *$ & \\
\hline Vif & 1.39 & 3.20 & 2.72 & \\
\hline $1 /$ vif & 0.71 & 0.31 & 0.36 & \\
\hline Source: Author' & outation using Sta & sion 12.0 & & \\
\hline
\end{tabular}

In correlation analysis, we can see that all independent variables are significant in their correlation analysis with dependent variable ROA, whereas with dependent variable ROE only investment in bank software is insignificant. All variables are within tolerable correlational limits which rule out the issue of multicollinearity. Values of vif for variables no. of Atm and total assets are moderately high. However, our applied technique of generalized method of moments is designed to correct for such issues.

Table 3: Results of DGMM Panel Regression Estimation

\begin{tabular}{lcc}
\hline \multicolumn{1}{c}{ Regression Model } & $\mathbf{1}$ & $\mathbf{2}$ \\
\hline Dependent Variable & ROA & ROE \\
Independent Variables & Coefficients & Coefficients \\
ROA $_{\mathrm{i}, \mathrm{t}-1}$ & $0.3969^{* * * *}$ & \\
ROE $_{\mathrm{i}, \mathrm{t}-1}$ & $(2.56)$ & $0.2207^{* * *}$ \\
$\mathrm{LNBS}_{\mathrm{i}, \mathrm{t}}$ & & $(5.13)$ \\
& & 0.0856 \\
LATM $_{\mathrm{i}, \mathrm{t}}$ & $0.0044^{* *}$ & $(1.63)$ \\
& $(1.93)$ & $-0.1273^{* *}$ \\
LNTA $_{\mathrm{i}, \mathrm{t}}$ & $-0.0078^{*}$ & $(-2.18)$ \\
& $(-1.85)$ & 0.0967 \\
Arellano-Bond test for AR(2) in first differences & & $(1.29)$ \\
& $0.0062^{*}$ & $\mathrm{Pr}>\mathrm{z}=0.262$ \\
\hline
\end{tabular}

${ }^{5} H_{0}$ : There is no second-order serial correlation in residuals

Sukkur IBA Journal of Management and Business - SIJMB | Volume 5 No. 2 July - December 2018 @ Sukkur IBA University 


$\begin{array}{lll}\text { Wald chi2 }(4)=13.31 & \text { Prob }>\text { hi2 }=0.010 & \\ \text { Wald chi2(4)=55.13 } & & \text { Prob }>\text { chi2 }=0.000 \\ \text { Hansen J-test of overidentifying restrictions }{ }^{6} & \text { Prob }>\text { chi } 2=.294 & \text { Prob }>\text { chi2 }=.360\end{array}$

Observations $=142 ;$ Banks $=25 ;$ Instruments $=24$

${ }^{* * *}$ Significance at $1 \%,{ }^{* *}$ significance at $5 \%$ and ${ }^{*}$ significance at $10 \%$ level of significance; $t$ - static are reported in parenthesis

Source: Authors computation from STATA version 12.0 special edition

In order to investigate relationship between IT proxies and profitability, model 1 and 2 are estimated by using DGMM Panel Regression Estimator and their results are reported in Table 3. Lagged values of dependent variables ROA and ROE have also been added to the right-hand side of the respective models. The co-efficient of both the lagged dependent variables is less than 1 which implies that our applied technique is valid, Second the lagged values of both dependent variables are positively related to their previous values, revealing the dynamic behavior of both the dependent variables $\mathrm{ROA}_{\mathrm{i}, \mathrm{t}}$ and $\mathrm{ROE}_{\mathrm{i}, \mathrm{t}}$, hence give rise to dynamic panel models. In order to examine the validity of instruments and specification of models different diagnostic tests have been applied sand their results are also presented in Table 3. The absence of serial correlation of second-order in residuals is the requirement for using GMM estimator. Results of second-order serial correlation test indicate the absence of second order serial correlation in both models. It implies that models are correctly specified and are valid. Wald chi test for both models are significant, hence both applied models are a good fit. Hansen J-statistic, is used to test the validity of instruments and their correct specification (Baum, 2006; Efendic et al., 2009). In our estimation for both the models, the null hypothesis of Hansen test of over identifying restrictions has not been rejected at the conventional levels of significance; hence, indicating instruments used in both models are valid.

Difference GMM results show that number of ATMs, a main variable of interest is significant at $10 \%$ level of significance in model 1 and significant at $5 \%$ level of significance in model 2. Therefore, it is evident that the impact of number of commercial banks, ATMs on the dependent variables ROA and ROE is considerable. Negative coefficients of LATM in both models infers that with increasing number of ATMs commercial banks profitability declines. Hence the results confirm the existence of profitability paradox for this component of IT (Gupta et. al, 2018). It is well known that ATMs are largely available over geographical areas and due to competition banks charge negligible fees to customers on using an ATM. Therefore, benefits from ATM are competed away, and hence do not translate into profits for banks. ATM as a component of IT for banks can be another delivery channel and may be termed as a

\footnotetext{
${ }^{6} \mathrm{H}_{0}$ : Model specification is correct and all overidentifying restrictions (all overidentified instruments) are correct (exogenous)

Sukkur IBA Journal of Management and Business - SIJMB | Volume 5 No. 2 July - December 2018 @ Sukkur IBA University 
social good due to its large availability and low prices (Berger 2003; Martín-Oliver \& Salas-Fumás, 2008). This implies to role of this IT component as a strategic requirement to stay competitive with other banks and not an IT surrogate that yields competitive advantage for banks (Beccalli, 2007). Additional investment in this component of IT may reap no actual benefits and profits for banks and may be a supplementary strategic necessity required for banks to remain competitive in the business, in fact, by not investing banks may experience decline in their market share (Parsad \& Harker, 1997). Hence, the findings provide a powerful evidence that the costs of adopting ATM technology exceeds the benefits yielded by it (Mahboub, 2018; Giordani \& Floros, 2015).

Investment in bank software, another variable of main interest, and control variable bank size are also significant at 5\% and $10 \%$ level of significance in table 3 . Whereas they are insignificant in model 2, therefore the relationship of these variables with ROE does not hold in the sample of this research. However, it may exhibit a different pattern in any other sample. A positive coefficient of bank software rejects existence of profitability paradox for this component of IT and infers that bank software has a positive impact on bank performance (Campanella, Della Peruta \& Del Giudice, 2017). As it augmenting banks' ability, to reduce costs associated with the collection, storage, processing and transmission of information (Goddard et al., 2007), to increase sale of banking products and services, by helping banks in achieving economies of scale via automation of operational tasks, by decreasing the time required for communication of information required by management, freeing up banking staff to focus on cross-selling (Meepadung, Tang \& Khang 2009), decreasing costs, by augmenting to enhance quality of outputs, and, more importantly, improvements in intangible aspects of products already on offer such as speed, maintenance of turnaround time, quality, and variety (Brynjolfsson \& Hitt, 2000). Positive coefficients of control variable entail the role of assets as economic resources to generate profit for banks (Safari \& Yu, 2014; Ou, et al., 2009).

Therefore, differently from existing literature the results add to our understanding that the impact of different components of IT on banks' profitability is mixed. Investment in bank software seems to have a positive influence on bank profitability, while the acquisition of ATMs negatively influences banks' performance. From our results we can interestingly conclude that benefits and problems are two conflicting faces of IT use that affect bank profitability in opposing directions. In short, it can be summarized that, IT is a wider term and encompasses many different components in itself. Hence, the present research argues that rather than taking IT as a whole and divulging into a paradox, it is prudent to analyze the impact of IT on banks profitability in components to have a clearer picture that how different components of IT impact profitability of banks. Due its empirical finding, this research is an important contribution to existing literature and concludes that IT paradox is not necessarily a paradox of IT in totality and should be termed as 'IT component paradox', which is a new term, as IT paradox may exist for a particular component of IT and may not in case of other.

Sukkur IBA Journal of Management and Business - SIJMB | Volume 5 No. 2 July - December 2018 () Sukkur IBA University 


\section{Recommendations}

Alternative IT distribution channels, such as ATM have abundant availability and low charges due to competition and benefits are thus passed on to customers. A prudent approach in this case for banks can be to join hands and install ATM under joint ownership and share expenses. In this manner customers still stand to gain the same advantage, but through joint ownership each banks' expenses will reduce and retail banking profits may get impacted positively through cost effectiveness. As banks today employ more advanced ERP based core banking software, they should make more robust and efficient use of these software to increase their range of products on offer to customers. Banks should view IT in components and as a profitability factor rather than a back-office supporting function, this could develop a sustainable competitive advantage and would improve the profitability of banking industry in the long run.

It can be noted that the subject area of this research is less explored in developing countries Therefore, future research in the area should be focused in these countries. Second, investigating the impact of IT by employing more measures of financial performance such as revenues, profits, sales growth, and return on investment. Data pertaining to IT is usually not easily available, the future researchers can employ additional proxies of IT based on availability of data to assess the impact of different components of IT on bank profitability.

\section{References}

Abubakar, A. A., \& Tasmin, R. B. H. (2012). The impact of information and communication technology on banks' performance and customer service delivery in the banking industry. International Journal of Latest Trends in Finance and Economic Sciences, 2(1), 80-90.

Acemoglu, D., Autor, D., Dorn, D., Hanson, G. H., \& Price, B. (2014). Return of the Solow paradox? IT, productivity, and employment in US manufacturing (Working paper No. w19837). Cambridge, Massacheutus, USA: National Bureau of Economic Research.

Alpar, P., \& Kim, M. (1990). A microeconomic approach to the measurement of information technology value. Journal of Management Information Systems, 7(2), 55-69.

Baum, C. F., Schaffer, M. E., \& Stillman, S. (2003). Instrumental variables and GMM: Estimation and testing. Stata Journal, 3(1), 1-31.

Baum, F. C. (2006). An Introduction to Modern Econometrics Using Stata. Texas, USA: Stata Press.

Beccalli, E. (2007). Does IT investment improve bank performance? Evidence from Europe. Journal of Banking \& Finance, 31(7), 2205-2230.

Berger, A. N. (2003). The economic effects of technological progress: Evidence from the banking industry. Journal of Money, Credit, and Banking, 35(2), 141-176.

Sukkur IBA Journal of Management and Business - SIJMB | Volume 5 No. 2 July - December 2018 @ Sukkur IBA University 
Bond, S. (2002). Dynamic Panel Models: A Guide to Micro Data Methods and Practice. Institute for Fiscal Studies (Working Paper No. CWP09/02). London, UK: University College London, Department of Economics, CEMMAP (Centre for Microdata Methods and practice).

Brynjolfsson, E. (1993). The productivity paradox of information technology. Communications of the ACM, 36(12), 66-77.

Brynjolfsson, E., \& Hitt, L. M. (2000). Beyond computation: Information technology, organizational transformation and business performance. The Journal of Economic Perspectives, 14(4), 23-48.

Campanella, F., Della Peruta, M. R., \& Del Giudice, M. (2017). The effects of technological innovation on the banking sector. Journal of the Knowledge Economy, 8(1), 356-368.

Dos Santos, B., \& Sussman, L. (2000). Improving the return on IT investment: the productivity paradox. International Journal of Information Management, 20(6), 429-440.

Dos Santos, B., \& Sussman, L. (2000). Improving the return on IT investment: the productivity paradox. International Journal of Information Management, 20(6), 429-440.

Efendic, A., Pugh, G., \& Adnett, N. (2009). Institutions and economic performance: System GMM modelling of institutional effects in transition. Unpublished Paper, Staffordshire University Business School, Stoke-on-Trent, UK. Retrieved from http://www.riinvestinstitute.org/pdf/Efendic et al.pdf

Eyadat, M., \& Kozak, S. J. (2005). The role of information technology in the profit and cost efficiency improvements of the banking sector. Journal of Academy of Business and Economics, 5(2), 70-75.

Giordani, G., \& Floros, C. (2015). Number of ATMs, IT investments, bank profitability and efficiency in Greece. Global Business and Economics Review, 17(2), 217-235.

Goddard, J., Molyneux,P., Wilson, J.O.S. and Tavakoli M. (2007). European banking: An overview. Journal of Banking \& Finance, 31(7), 1911-1935.

Gupta, S. D., Raychaudhuri, A., \& Haldar, S. K. (2018). Information technology and profitability: evidence from Indian banking sector. International Journal of Emerging Markets, 13(5), 1070-1087.

Hernando, I., \& Nieto, M. J. (2007). Is the Internet delivery channel changing banks' performance? The case of Spanish banks. Journal of Banking \& Finance, 31(4), 1083-1099.

Hitt, L. M., \& Brynjolfsson, E. (1996). Productivity, business profitability, and consumer surplus: three different measures of information technology value. MIS quarterly, 20(2), 121-142.

Ho, S. J., \& Mallick, S. K. (2006). The impact of information technology on the banking industry: Theory and empirics. Queen Mary, University of London, UK. Retrieved form http://webspace.qmul.ac.uk/pmartins/mallick.pdf

Sukkur IBA Journal of Management and Business - SIJMB | Volume 5 No. 2 July - December 2018 @ Sukkur IBA University 
Ho, S. J., \& Mallick, S. K. (2010). The impact of information technology on the banking industry. Journal of the Operational Research Society, 61(2), 211-221.

Holden, K., \& El-Bannany, M. (2004). Investment in information technology systems and other determinants of bank profitability in the UK. Applied Financial Economics, 14(5), 361-365.

Jalal-Karim, A., \& Hamdan, A. M. (2010). The impact of information technology on improving banking performance matrix: Jordanian Banks as case study. Paper presented at the European Mediterranean and Middle Eastern Conference on Information System. Retrieved from http://blog.stikom.edu/erwin/files/2012/08/the-impact-of-information-technologyon-improving-banking-performance-matrix-jordanian-banks-as-case-study.pdf

Jesudasan, S., Pinto, P., \& Prabhu, R. (2013). Impact of Investment in Information Technology on Performance of Banks and National Economy: A Study with respect to Karnataka Bank Ltd. Gian Jyoti E-Journal, 3(2), 94-103.

Karimzadeh, D. S. D., Emadzadeh, D. M., \& Shateri, J. (2014). The Effects Of Electronic Banking Expansion On Profitability Of A Commercial Bank (Sepah Bank Of Iran). Indian J. Sci. Res., 4(6), 305-312.

Kauffman, R. J., \& Banker, R. D. (1991). Case study of electronic banking at Meridian Bankcorp. Information and Software Technology, 33(1), 200-204.

Lee, H., Choi, H., Lee, J., Min, J., \& Lee, H. (2016). Impact of IT Investment on Firm Performance Based on Technology IT Architecture. Procedia Computer Science, 100(91), 652-661.

Mahboub, R. M. (2018). The Impact of Information and Communication Technology Investments on the Performance of Lebanese Banks. European Research Studies Journal, 21(4), 435-458.

Meepadung, N., Tang, J. C., \& Khang, D. B. (2009). IT-based banking services: Evaluating operating and profit efficiency at bank branches. The Journal of High Technology Management Research, 20(2), 145-152.

Mehmood, B., Shafique, A., \& Rafaqat, R. (2014). Is Solow's Paradox Absent in World Leading Capital Markets? Econometric Evidence. Romanian Economic Journal, 17(52), 45-62.

Mittal, R. K., \& Dhingra, S. (2007). Assessing the impact of computerization on productivity and profitability of Indian banks: an application of data envelopment analysis. Delhi Business Review, 8(1), 63-73

Mustafa, S., \& Mehmood, B. (2015). Efficiency Change in Pakistan Commercial Banking Sector: A Pre and Post Digital-Restructuring Analysis. Journal of Emerging Economies and Islamic Research (JEEIR), 3(1), 1-12.

Onay, C., Ozsoz, E., \& Helvacioğlu, A. D. (2008). The impact of Internet-Banking on Bank Profitability-The Case of Turkey. Paper presented at the Oxford Business \& Economics Conference Program. Retrieved from http://gcbe.uswww.gcbe.us/2008_OBEC/data/Ceylan\%20Onay,\%20Emreozsoz, \% 20Asli\%20Deniz\%20Helvacioglu.doc

Sukkur IBA Journal of Management and Business - SIJMB | Volume 5 No. 2 July - December 2018 @ Sukkur IBA University 
Ou, C. S., Yen, D. C., \& Hung, C. S. (2009). Determinants of information technology investments: The case of ATM in an emerging economy. Advances in Accounting, 25(2), 278-283.

Prasad, B., \& Harker, P. T. (1997). Examining the contribution of information technology toward productivity and profitability in US retail banking (Working Papers\# 97-09). Philladelphia, Pennsylvania, USA: The Wharton Financial Institutions Center.

Rauf, S., Qiang, F., \& Sajid, K.U. (2014). Electronic Debit Card Usage and their Impact on Profitability of Pakistan Banking Sector: ROA, Model. European Journal of Business and Management, 6(4), 1-7.

Roodman, D. (2006). How to do xtabond2: An introduction to "Difference" and "System" GMM in Stata (Working Paper 103). Northwestern, USA: Center for Global Development.

Roodman, D. (2007). A Short Note on the Theme of Too Many Instruments (Working Paper No. 125) Northwestern, USA: Center for Global Development.

Roodman, D. (2009). How to do xtabond2: An Introduction to "Difference" and "System" GMM in Stata. Stata Journal 9(1), 86-136.

Safari, M. R., \& Yu, L. Z. (2014). Impact of Information and Communication Technology (ICT) on Efficiency: Evidence from the Iranian Banking Industry. World Applied Sciences Journal, 29(2), 208-218.

Sarafidis, V., Yamagata, T., \& Robertson, D. (2009). A test of cross section dependence for a linear dynamic panel model with regressors. Journal of Econometrics, 148(2), 149-161.

Shaoa, B. B., \& Lin, W. T. (2002). Technical efficiency analysis of information technology investments: a two-stage empirical investigation. Information \& Management, 39(5), 391-401.

Shu, W., \& Strassmann, P. A. (2005). Does information technology provide banks with profit? Information \& Management, 42(5), 781-787.

Solow, R.M. (1987, July 12). We'd better watch out. New York Times Book Review. Retrieved from http://www.standupeconomist.com/pdf/misc/solow-computerproductivity.pdf

Stratopoulos, T., \& Dehning, B. (2000). Does successful investment in information technology solve the productivity paradox? Information \& Management, 38(2), 103-117.

State Bank of Pakistan (2012). Annual Performance Review. Retrieved from http://www.sbp.org.pk/reports/annual/arFY12/Vol-2/eng/CompleteReport.pdf

Swierczek, F. W., \& Shrestha, P. K. (2003). Information technology and productivity: a comparison of Japanese and Asia-Pacific banks. The Journal of High Technology Management Research, 14(2), 269-288.

Tahir, S. H., Shah, S., Arif, F., Ahmad, G., Aziz, Q., \& Ullah, M. R. (2018). Does financial innovation improve performance? An analysis of process innovation used in Pakistan. Journal of Innovation Economics Management, 27(3), 195-214.

Sukkur IBA Journal of Management and Business - SIJMB | Volume 5 No. 2 July - December 2018 @ Sukkur IBA University 
Thakur, M. S. (2018). The Impact of Information Technology Advancement in Indian Banking Sector. International Journal of Engineering Technology Science and Research, 5(1), 833-841.

Vekya, J.M. (2017). Impact of Electronic Banking on the Profitability of Commercial Banks in Kenya. Journal of Technology and Systems, 1(1), 18-39.

Sukkur IBA Journal of Management and Business - SIJMB | Volume 5 No. 2 July - December 2018 @ Sukkur IBA University 